\title{
Spatio-temporal variability of climatic parameters across different altitudes of North- Western Himalaya
}

\author{
PANKAJ PANWAR ${ }^{1}$ *, SHARMISTHA PAL ${ }^{1}$, NANCY LORIA ${ }^{1}$, MED RAM VERMA ${ }^{3}$, N.M. ALAM ${ }^{2}$, \\ V.K. BHATT ${ }^{1}$ and N.K. SHARMA ${ }^{2}$
}

\author{
${ }^{1}$ ICAR-Indian Institute of Soil and Water Conservation, Sector 27 A, Research Center Chandigarh - 160019 - INDIA; \\ ${ }^{2}$ ICAR-Indian Institute of Soil and Water Conservation 218 Kaulagarh Road-Dehra Dun; \\ ${ }^{3}$ ICAR-Indian Veterinary Research Institute, Izzatnagar, Uttar Pradesh \\ *corresponding author; Email: dr_pankajp@yahoo.co.in
}

\begin{abstract}
Climate change impact varies across different altitudinal ranges and demands local specific management strategies for water resource and farming system management. The present study analyses spacio-temporal climate parameters across different altitudes of Himachal Pradesh a hilly state of India. Analysis shows that annually, minimum temperature has significantly decreased by $-0.09^{\circ} \mathrm{C}$ at altitude I (350- $400 \mathrm{~m}$ ) while maximum temperature has significantly increased by $0.05^{\circ} \mathrm{C}$ at altitudes I and II (1400$1500 \mathrm{~m}$ ) and decreased significantly by $-0.08^{\circ} \mathrm{C}$ at altitude III (2000- $2100 \mathrm{~m}$ ). Higher regions Altitude - IV $(2900-3000 \mathrm{~m})$ received lowest rainfall $(746.1 \mathrm{~mm})$ with $30.2 \%$ variation. Seasonal rainfall variability was higher in post monsoon (102 - 174\%) and least in monsoon (21 - 57\%). Annual rainfall at altitude I is strongly irregular ( $\mathrm{PCl} 20.1$ to 22.3), followed by altitude - IV (PCI 15-25); altitude - II irregular (PCI 15-20) and altitude - III moderate to irregular (PCI 12 -19) rainfall. Seasonal Index values for four altitudes fall between 0.91-0.96 revealed that rainfall is irregular and markedly seasonal with longer drier season. Higher wavelet powers in altitude - I and II after 2005 suggests frequency of extreme rainfall occurrence had increased.
\end{abstract}

Key Words: Altitude, precipitation concentration index, rainfall, seasonality index, temperature, wavelet analysis

Climate change is inevitable; however, it is imperative to known the variability of climate change so that necessary measures can be taken at local levels for adapting to such changes. Indian economy is largely agricultural based. Agriculture is a climate sensitive sector and any change in climate will have direct or indirect impact on agricultural productivity by affecting the crop yield, water availability and associated drought stress, pest-diseases etc affecting economy of the country. Cropping intensity and cropping area are also greatly influenced by the climatic variability (Kotera et al. 2014). Extreme temperature and rainfall variability have significant negative impacts on crop production. It was observed that temperature have more significant positive or negative impact on crop production as compared to rainfall (Lobell et al. 2011). Other impacts of climate change include higher runoff from the fields and increased soil erosion due to more frequent intense rainfall events. Piao et al. (2010) opined that the impact of climate change plays a pivotal role for future agricultural planning and crop production in the world, including India.

North Western (NW) Himalayan region of India covers states of Jammu and Kashmir, Himachal Pradesh and Uttrakhand. About 1.6 degree of temperature rise in the NW Himalayan region was reported in the last century (19012002) by Bhutiyani et al. (2007). Significant increasing trend of $0.06^{\circ} \mathrm{C}_{\text {year }}{ }^{-1}$ on annual mean maximum temperatures and $0.02{ }^{\circ} \mathrm{C}_{\text {year }}{ }^{-1}$ on annual mean temperatures for the $1951-2010$ time period were observed for Himachal Pradesh (Rathore et al. 2013). Increasing trend over the central India region for the period 1950-2000 was also observed for number of rainfall events per year with precipitation greater than $100 \mathrm{~mm}$ whereas number of moderate rainfall events had shown decreasing trend in the same period (Goswami et al. 2006). Decreased number of rainfall events but increasingly common high rainfall events was reported by Dourte et al. (2012). The impacts of such extreme events in hills will leads to migration of species towards higher altitudes, loss/drying of traditional water sources, changes in planting time and dates, reduced crop yields and increased vulnerability of farming communities to climatic changes.

It is therefore, important to know trends of temperature and rainfall in space and time at local levels so that region 
specific interventions can be advocated for adaptation under changing climatic conditions. Pawar et al. (2019) have analysed trends of rainfall and temperature at Shimla and Dharmshala. In this paper we aim to analyse the temperature and rainfall trend and pattern over different altitude of Himachal Pradesh on monthly, seasonal and annual timescale.

\section{MATERIALS AND METHODS}

\section{Study area}

Himachal Pradesh is located between $30^{\circ} 22^{\prime} 40^{\prime \prime} \mathrm{N}$ to $33^{\circ} 12^{\prime} 40^{\prime \prime} \mathrm{N}$ latitudes and $75^{\circ} 45^{\prime} 55^{\prime \prime} \mathrm{E}$ to $79^{\circ} 04^{\prime} 20^{\prime \prime} \mathrm{E}$ longitudes. The state has a hilly terrain and complex topography with the altitude ranging from 350 meters to 7000 meters above sea level. The annual rainfall of the state varies from $2909-3800 \mathrm{~mm}$ and temperature ranges from $-4^{\circ} \mathrm{C}$ (minimum) to $42^{\circ} \mathrm{C}$ (maximum). Based on its altitude, precipitation and varied cropping patterns, the state is divided into four agro climatic zones : Low-hill subtropical zone, midhill subhumid zone, high-hill temperate wet zone and high hill temperate dry zone. One station from each of the four agroclimatic zones was selected for the study.

\section{Data source}

Different stations located at varying altitudes were selected for study (Table 1). Monthly temperature (minimum and maximum) and rainfall data of selected stations of Himachal Pradesh for years 1980-2015 were collected from India Meteorological Department (IMD), Regional Research Station Shimla. Four Principal seasons observed in the state are winter (December, January, February), pre monsoon (March, April, May), monsoon (June, July, August, September) and post monsoon (October, November).

\section{Trend analysis}

Monthly, annual and seasonal trends of temperature and rainfall were computed using non-parametric MannKendall (MK) statistic (Mann, 1945; Kendall, 1975). This MK test is recommended by the World Meteorological Organization and has been widely used to test for trends in hydrological and meteorological data, including precipitation, temperature and runoff (Li et al. 2008; Zang and Liu, 2013). The change in trend per unit time was calculated using non parametric Sen's slope estimator (Sen, 1968). The Sen's slope estimator is computed by choosing the median of the slopes of all lines through pairs of points as follows:

$\mathrm{b}=\operatorname{median}\left[\frac{\mathrm{x}_{\mathrm{j}}-\mathrm{x}_{\mathrm{i}}}{\mathrm{j}-\mathrm{i}}\right]$ for all $\mathrm{i}<j$
The direction of change and the rate of increase or decrease in the annual and seasonal trend is revealed through the slope (Choudhury et al. 2012).

\section{Precipitation concentration index (PCI)}

Long-term total variability in the amount of rainfall was assessed using Precipitation Concentration Index (Oliver, 1980). It is taken as an indicator of rainfall concentration and rainfall erosivity (Michiels et al. 1992). PCI was calculated on an annual and seasonal scale as follows:

PCI (annual $)=\frac{\sum_{1=i}^{12} p_{i}{ }^{2}}{\left(\sum_{1=i}^{12} p_{i}\right)^{2}} * 100$

where $\mathrm{p}_{\mathrm{i}}$ is the monthly precipitation in $\mathrm{i}^{\text {th }}$ month .

$P C I($ seasonal $)=\frac{\sum_{1=i}^{n} p_{i}{ }^{2}}{\left(\sum_{1=i}^{n} p_{i}\right)^{2}} * \frac{n}{12} * 100$

Where $\mathrm{n}$ is the no. of the months in a season.

PCI was computed on five yearly basis. PCI values are interpreted differently by different studies (Table 2).

\section{Seasonality index}

Seasonality comparison for different altitudes in a state or over different locations in a larger region is possible only when there is some quantitative tool for accounting for rainfall regimes (Adejuwon, 2012). Rainfall regimes are important to know the degree of variability in monthly rainfall throughout the year (Walsh and Lawer, 1981). Seasonality Index (SI) is a function of mean monthly and annual rainfall and was estimated using the following formula:

$S I=\frac{1}{R} \sum_{1=n}^{21}\left|X_{n}-\frac{R}{12}\right|$

Where $X_{n}$ is the mean rainfall of month $n$ and $R$ is the mean annual rainfall. The SI values ranges from zero (if all the months have equal rainfall) to 1.83 (if all the rainfall occurs in one month). Different rainfall regimes with respect to SI values (Kanellopoulou, 2002) is given in Table 3.

\section{Change point analysis}

Change-point analysis is a powerful tool for detecting a change in the time series. Abrupt changes occurring in the climatic records are evaluated using non- parametric Pettitt's test, developed by Pettitt (1979). The Pettitt's test affectability to breaks in the middle of any time series make it the most commonly used test for change point detection (Winingaard et al. 2003). The exact time of the change can be easily obtained 
Table 1: Selected stations, their altitude and zonation

\begin{tabular}{llll}
\hline S.No. & Station & Altitude $($ metres amsl*) & Agroclimatic Zone \\
I & Altitude I & 369 & Sub montane, Low Hills, Sub tropical Zone \\
II & Altitude II & 1453 & Mid Hills, Sub Humid Zone \\
III & Altitude III & 2050 & High Hills, Temperate Wet \\
IV & Altitude IV & 2960 & High Hills, Temperate Dry
\end{tabular}

* above mean sea level

Table 2: Intrepretation of PCI values by different authors.

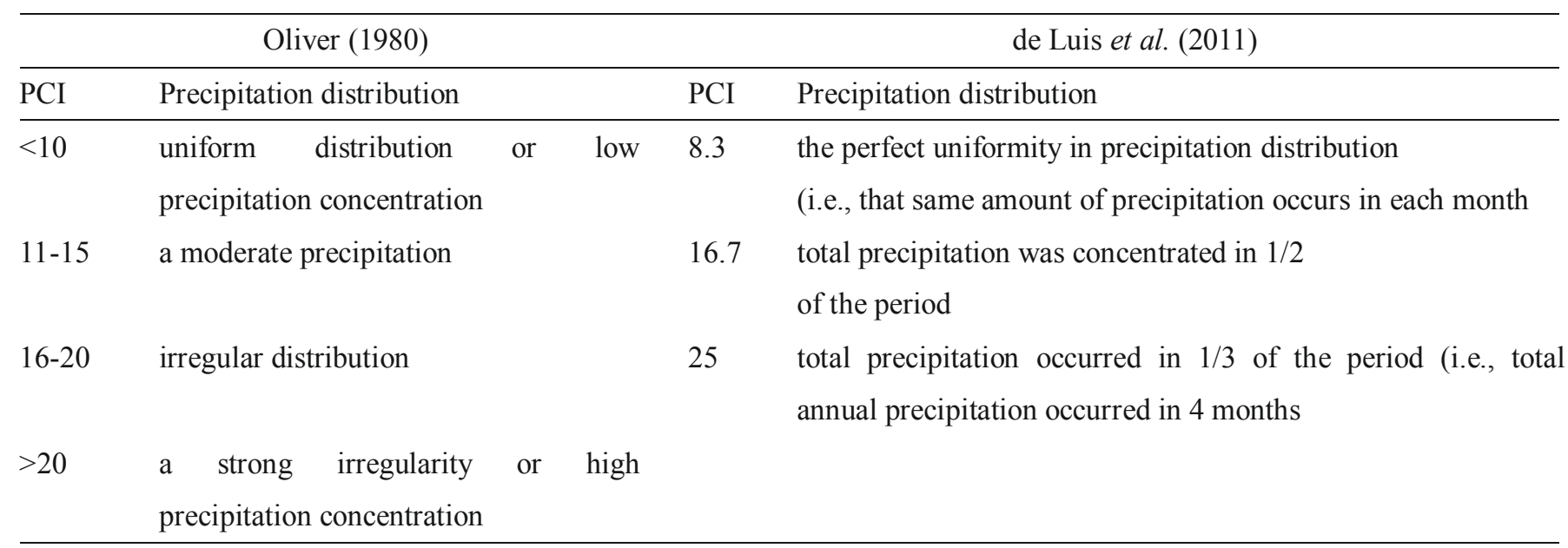

Table 3: Rainfall regimes and their respective SI values

Rainfall regime Seasonality index (SI)

Very equable

Equable but with a definite wetter season

Rather seasonal with a short drier season

Seasonal

Markedly seasonal with a long drier season

Most rain in three months or less

Extreme almost all rain in $1 \pm 2$

$\geq 1.2$

by detecting a significant change in the mean of a time series. Many studies have explained the test statistics used in Pettitt's test (Jana et al. 2017; Dhorde and Zarenistanak, 2013; Kang and Yusof, 2012; Gao et al. 2011).

\section{RESULTS AND DISCUSSION}

\section{Spatial temperature and rainfall distribution}

Analysis of temperature revels that annual minimum and maximum temperature varied from $4.5-15.6{ }^{\circ} \mathrm{C}$ and 15.9 $-30.0{ }^{\circ} \mathrm{C}$ respectively. Minimum temperature was in AltitudeIV with $19.6 \%$ variation and maximum temperature was in
Altitude- I with $6.3 \%$ variation. The annual rainfall varied from $746.1-1398 \mathrm{~mm}$ with an average of $1075.8 \mathrm{~mm}$. Higher region (Altitude $-\mathrm{IV}$ ) received lowest rainfall $(746.1 \mathrm{~mm})$ with $30.2 \%$ variation and Altitude - II received highest (1398 $\mathrm{mm}$ ) rainfall with $17.9 \%$ variation. For minimum temperature, maximum temperature and rainfall higher variation was $36.9 \%, 13.7 \%$ and $42.0 \%$ respectively in altitude-III (Table 4).

\section{Monthly and seasonal distribution}

Monthly temperature distribution pattern indicates 


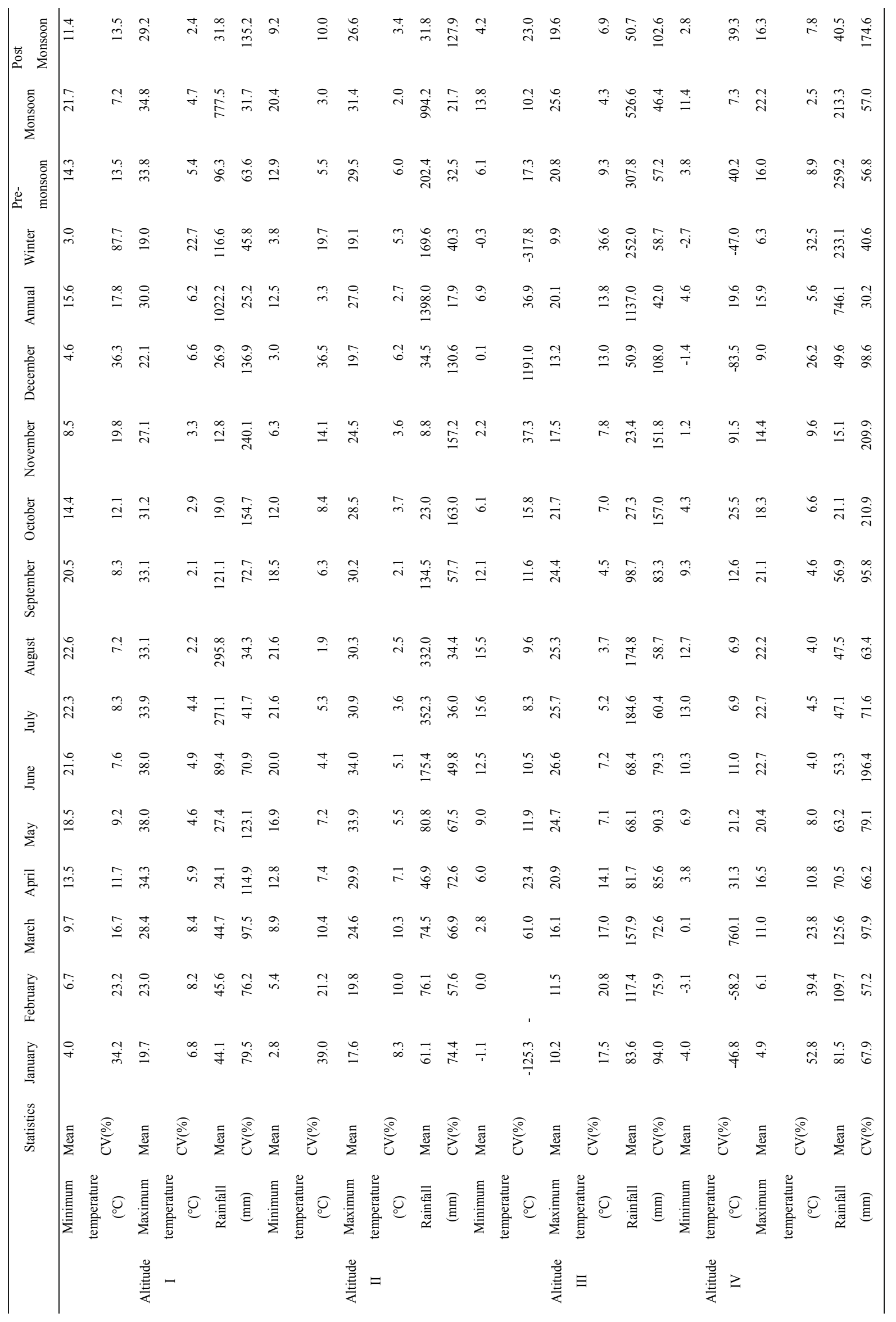




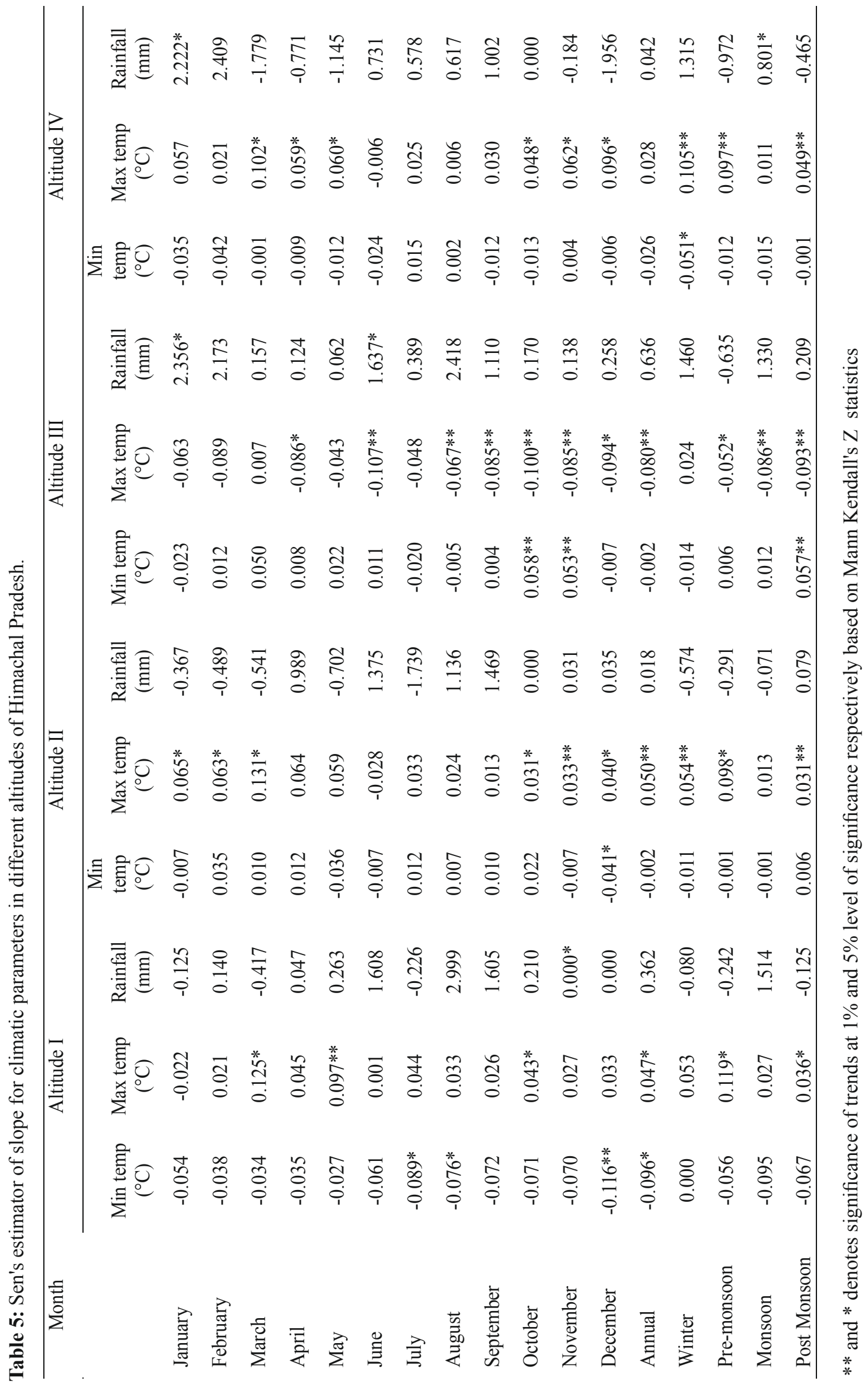


mean minimum temperature was lower in January in all four altitudes ranging from $-4.0-4.0{ }^{\circ} \mathrm{C}$. Mean maximum temperature was higher in the month of June $\left(22.7-33.9^{\circ} \mathrm{C}\right)$ in altitude II, III and IV whereas, it was higher $\left(38.1{ }^{\circ} \mathrm{C}\right)$ in altitude - I in May. Variation for minimum temperature was higher $(-125.4 \%)$ for altitude - III in January. Maximum temperature variability was higher $(53.0 \%)$ in January for altitude - IV. Mean monthly rainfall was higher in July in altitude - II (352.3 mm) and altitude - III (184.6 mm). Rainfall variability was higher $(240.1 \%)$ in November at altitude - I (Table 4).

Seasonal temperature analysis implies that average minimum temperature was higher $\left(11.4-21.7{ }^{\circ} \mathrm{C}\right)$ in monsoon and least $\left(-2.6-3.7^{\circ} \mathrm{C}\right)$ in winter season. Average maximum temperature was higher $\left(22.2-34.8{ }^{\circ} \mathrm{C}\right)$ in monsoon season. Variation of minimum temperature was higher (-317.8\%) in winter and for maximum temperature it was also higher (36.6 $\%$ ) in winter in altitude - III. Seasonal rainfall variability was higher in post monsoon (102.6 - 174.6\%) and least in monsoon $(21-57 \%)$ (Table 4$)$.

\section{Monthly trends}

Minimum temperature has significantly decreasing trend during July, August and December by $0.09^{\circ} \mathrm{C}, 0.08^{\circ} \mathrm{C}$ and $0.12{ }^{0} \mathrm{C}$ respectively for the altitude I. Significant decreasing trend in minimum temperature $\left(0.04^{\circ} \mathrm{C}\right)$ was found for December in altitude II. Minimum temperature of October and November had significant increasing trend of $0.06^{\circ} \mathrm{Cand}$ $0.05^{\circ} \mathrm{C}$ respectively for Altitude III (Table 5)..

Significant increase in maximum temperature by $0.12^{\circ} \mathrm{C}, 0.1^{\circ} \mathrm{C}$ and $0.04^{\circ} \mathrm{C}$ was observed during the months of March, May and October, respectively for lowest Altitude I. However, significant increase in maximum temperature by $0.1^{\circ} \mathrm{C}, 0.06^{\circ} \mathrm{C}, 0.06^{\circ} \mathrm{C}, 0.05^{\circ} \mathrm{C}, 0.06^{\circ} \mathrm{C}$ and $0.1^{\circ} \mathrm{C}$ was observed during March, April, May, October, November and December, respectively in Altitude - IV. No significant trend in rainfall was observed for Altitude I and II (Table 5). At altitude - III, rainfall showed significant increase by $2.36 \mathrm{~mm}$ and 1.64 $\mathrm{mm}$ during the months of January and June, respectively. Significant increase in rainfall by $2.22 \mathrm{~mm}$ in the month of January was also observed for the altitude - IV.

\section{Seasonal and annual trends}

Magnitude of seasonal temperature and rainfall trend was analyzed and is presented in Table 5. Maximum temperature showed a significant increasing trend in most of the seasons. Minimum temperature had a decreasing trend in most of the season. However, significant decrease was (-0.051 ${ }^{0} \mathrm{C}$ ) was observed for altitude - IV during winter season. Monsoon rainfall in altitude-IV had a significant increasing trend. Decreasing trend of winter rainfall in lower altitudes (altitude - I and II) and its increasing trend in higher altitudes (altitude - III and IV) are cause of concern and requires contingency planning. At lower altitude, which is agricultural production areas, rainfall trends show increased concentration in monsoon and its decrease in other all seasons. Such changes on one hand will hamper winter cropping and on the other creates flood like situation during rainy season. Annual trend shows significant increase in maximum temperature in lower altitudes.

\section{Seasonal rainfall concentration}

Pattern of rainfall distribution was assessed using PCI on 5 yearly bases. Annual and seasonal PCI values varied from lower than 10 in the monsoon season to higher than 30 in the post-monsoon season (Fig 2). Annual rainfall at altitude $\mathrm{I}$ is strongly irregular (PCI 20.14 to 22.37), followed by altitudeIV with PCI moderate to strongly irregular (PCI 15-25); altitude - II irregular (PCI 15-20) and altitude - III moderate to irregular (PCI 12 -19) rainfall. This shows that annual rainfall is unevenly distributed among the months and is concentrated more in one third of the year.

Seasonal PCI showed mixed rainfall distribution in pre-monsoon, post-monsoon and winter rainfall with PCI values varying from 9 to 46 . This shows highly irregular and unpredictable nature of rainfall during the seasons. This uncertainly in rainfall affects the pre-kharif and rabi crop sowing and management (Jana et al. 2017). Monsoon season shows relatively stable and uniform rainfall concentration with PCI in a range of 9-15. Highest PCI values were for post monsoon season in all altitudes with highest PCI values in altitude - I.

\section{Seasonality index}

Seasonal Index values for four altitudes fall between 0.91-0.96 (Fig. 2). Decadal trend of rainfall is decreasing for all altitudes except for altitudes I and II for the decade of 198089 which had an increasing trend. Over all decreasing trend agrees with the fact that monsoon rainfall is decreasing and on the other hand pre- and post-monsoon rainfall is increasing which in fact reduces the rainfall concentration disparity. This suggests that there a relative shifting in rainfall pattern with passing time with inconsistency in rainfall. Similar observations were made for the state of Kerala by Nair et al. (2014), Bundelkhand by Jana et al. 2017 and Thomas and 

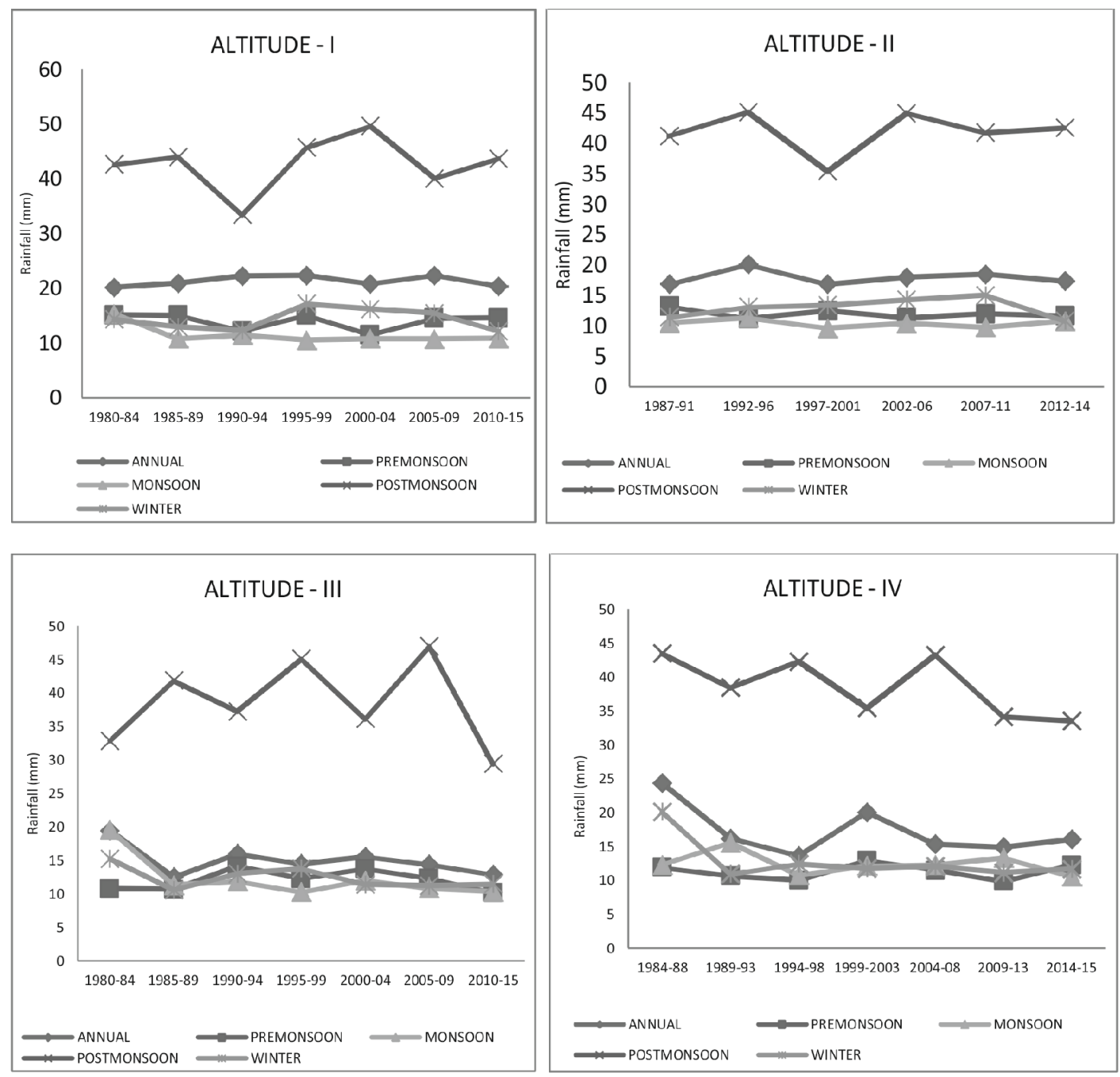

Fig. 1: Annual and seasonal PCI over four different altitudes

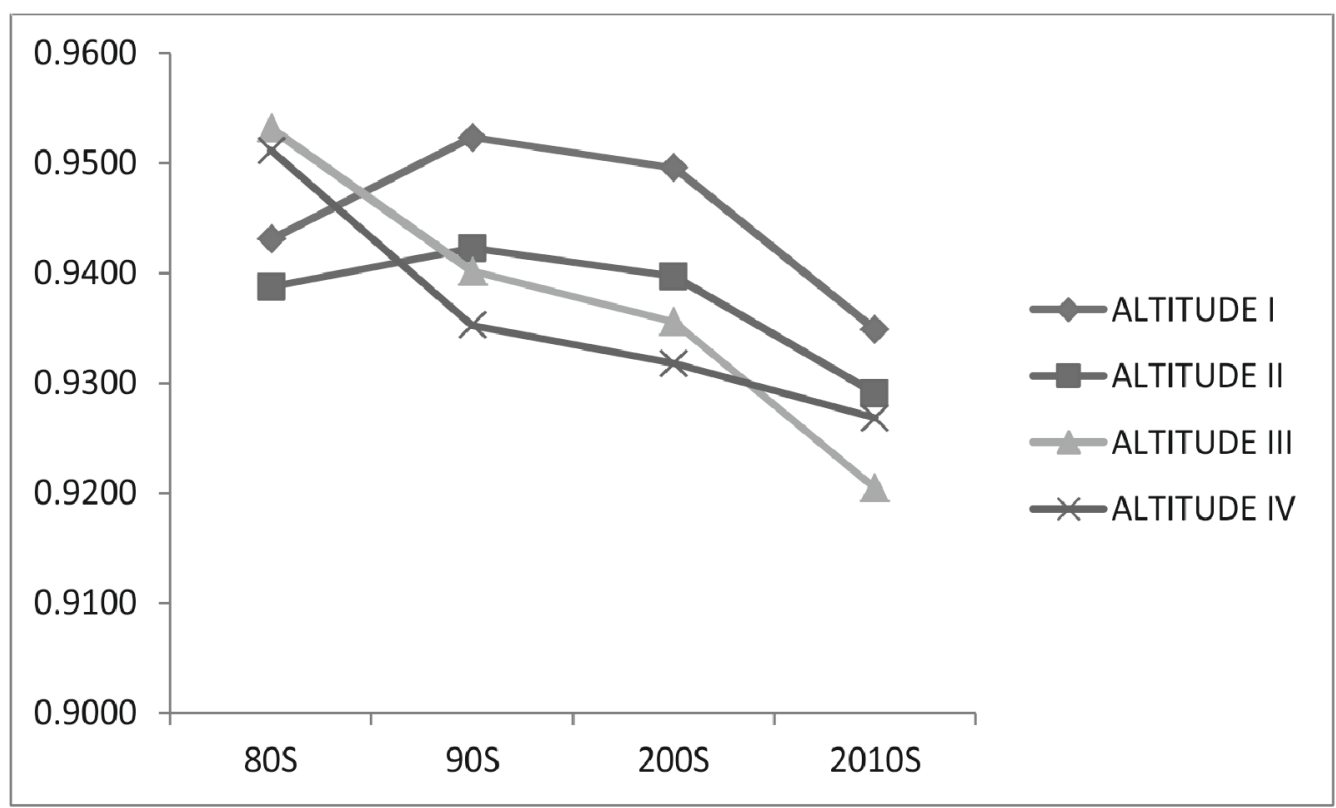

Fig. 2: SI values for different altitudes 

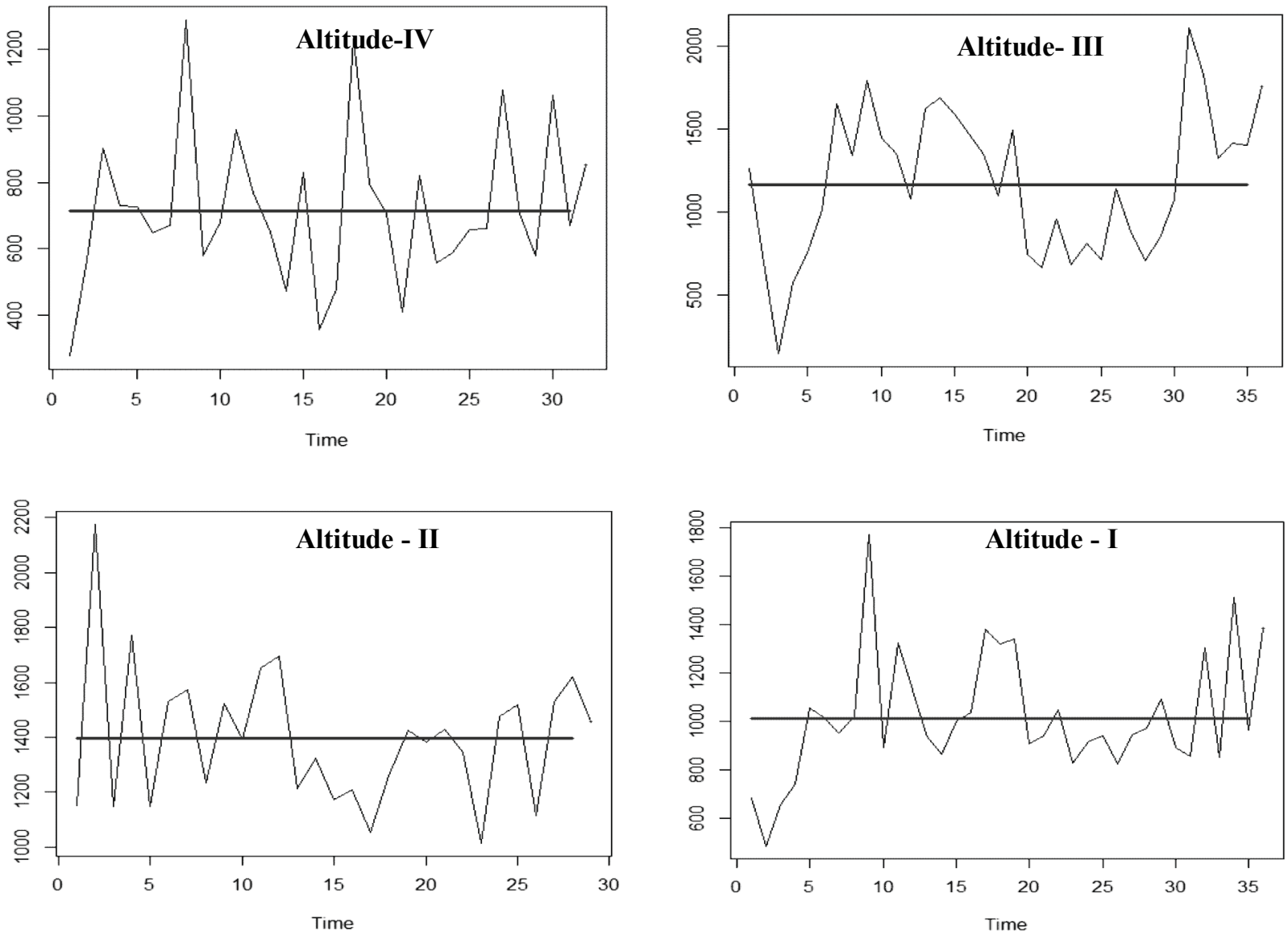

Fig. 3: Time series along with change year using Pettitt change point analysis for annual rainfall
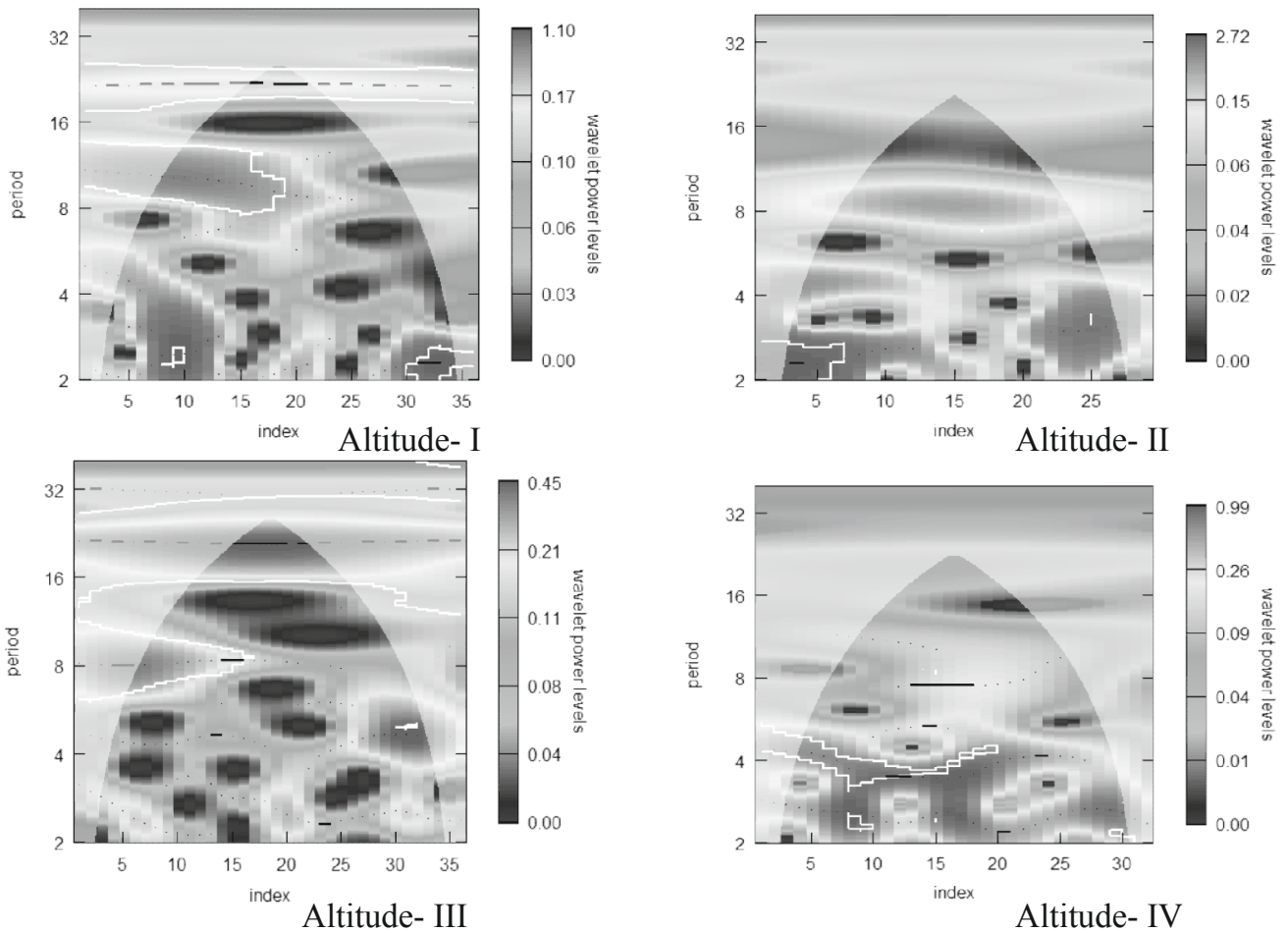

Fig. 4: Wavelet analysis for annual rainfall for four altitudes 
Prasannakumar, 2016 who had reported mixed but slight decreasing trend in the time series.

\section{Change point analysis}

Annual series of rainfall was analyzed using Pettitt's test for change detection analysis. Time series of annual rainfall with the change points is presented in Fig. 3. The change point analysis on time series of annual rainfall indicated that significant change points in all the altitudes was in year 2014 from where above average rainfall was observed. The significant change points in the series observed during 2014 may be attributed to the growing commercial activities in the region (Jaiswal et al. 2015). Besides 2014, change point was also found in 1998 (showing decreased rainfall), 1983 (showing increased rainfall) and 2009 (showing decreased rainfall) for altitude-II, altitude-I and altitude-III, respectively. Change point in 1990's was also observed for Agra district, India (Jana et al. 2016)

\section{Rainfall periodicity}

Wavelet analysis for annual rainfall periodicity is given in Fig. 4 for all the four altitudes. It was found that periodicity of rainfall in altitude - I had decreased and remained almost similar in other altitudes. Higher wavelet powers in altitude - I and II after 2005 suggests frequency of extreme rainfall occurrence had increased. Dash et al. (2012) while analysing rainfall characteristics over nine agrometeorological divisions also found that heavy intensity rainfall spells are increasing. In altitude III the periodicity of such extreme events has also increased from $7-24$ years (during 1980 to 1995 ) to $4-24$ years (during 2006 to 2015). A periodicity of 2-8 years was found in annual and seasonal rainfall patterns in Kerala state, India (Thomas and Prasannakumar, 2016).

\section{CONCLUSIONS}

The study reveals that annual variability was more for minimum temperature $(19.6 \%)$ in higher altitude and for maximum temperature in lower altitude. Winter season showed maximum variation for both minimum and maximum temperature in altitude - III. Monsoon rainfall is the major contributor to the annual rainfall and has higher consistency compared to other seasons. Rainfall variability was higher in post-monsoon $(102-145 \%)$. At lower altitude, which is agricultural production areas, rainfall trends show increased concentration in monsoon and its decrease in other seasons. Maximum PCI values also confirm that annual rainfall amount is highly variable and is concentrated in the $2-3$ months of the monsoon season. PCI values were higher for post-monsoon in altitude - I. High seasonal index values (0.91-0.96) revealed that rainfall is irregular and markedly seasonal with longer drier season. Higher wavelet powers in altitude - I and II after 2005 suggests frequency of extreme rainfall occurrence had increased.

\section{ACKNOWLEDGEMENT}

The authors acknowledge the funding received under NMSHE project from Department of Science and Technology, Government of India. Authors acknowledge IMD- Shimla for providing meteorological data. Authors also acknowledge any direct and indirect help rendered by scientific and technical staff of the ICAR-IISWC, RC-Chandigarh during course of present research work.

\section{REFERENCES}

Adejuwon, J. O. (2012). Rainfall seasonality in the Niger Delta Belt, Nigeria. J. Geogr Reg. Plann., 5(2): 51-60.

Bhutiyani, M.R, Kale, V.S. and Pawar, N.J. (2007). Long-term trends in maximum, minimum and mean annual air temperatures across the North-western Himalaya during the twentieth century. Clim. Change, 85(1-2) : 159-177.

Choudhury, B. U., Das, A., Ngachan, S. V., Slong, A., Bordoloi, L. J. and Chowdhury, P. (2012). Trend analysis of long term weather variables in mid altitude Meghalaya, North-East India . J. Agric. Phy., 12 (1): 12-22.

Dash, S.K., Nair, A.A., Kulkarni, M.A. and Mohanty, U.C. (2012). Characteristic changes in the long and short spells of different rain intensities in India. Theoretical and Applied Climatology. http://dx.doi.org/10.1007/ s00704-011-0416-x.

De Luis, M., Gonzalez-Hidalgo, J. C., Brunetti, M. and Longares, L. A. (2011). Precipitation concentration changes in Spain 1946-2005. Nat. Hazards Earth Syst. Sci., 11 (5): 1259-1265.

Dhorde, A.G. and Zarenistanak, M. (2013). Three-way approach to test data homogeneity: an analysis of temperature and precipitation series over southwestern Islamic Republic of Iran, J. Ind. Geophys. Union, 17(3): 233-242.

Dourte, D.R., Shukla, S., Singh, P. and Haman, D. (2012). Rainfall intensity-duration-frequency relationships for Andhra Pradesh, India: changing rainfall patterns and implications for runoff and groundwater recharge. J. Hydrol. Eng., 18 (3) : 324-330. 
Gao, P, Mu, X. M., Wang, F. and Li, R. (2011). Changes in stream flow and sediment discharge and the response to human activities in the middle reaches of the Yellow River. Hydrol Earth Syst. Sci, vol. 15 : 1-10.

Goswami, B. N., Venugopal, V., Sengupta, D., Madhusoodanan, M. S, Xavier and Prince K. (2006). Increasing Trend of Extreme Rain Events over India in a Warming Environment. Science, 314 (5804):1442-45.

Jaiswal, R. K., Lohani, A. K. and Tiwari, H. L. (2015). Statistical Analysis for Change Detection and Trend Assessment in Climatological Parameters. Environ. Process., 2: 729-749.

Jana, C., Alam, N. M., Mandal, D., Shamim, M. and Kaushal, R. (2017). Spatio-temporal rainfall trends in the twentieth century for Bundelkhand region, India. $J$. Water Climate Change, 8(3): 441-455.

Jana, C., Sharma, G. C., Alam, N. M., Mishra, P. K., Dubey, S. K. and Kumar, R. (2016). Trend analysis of rainfall and rainy days of agra in northern India. Int. J. Agric. Stat. Sci., 12(1): 263-270.

Kanellopoulou, E. A. (2002). Spatial distribution of rainfall seasonality in Greece. Weather, 57 : 215-219.

Kang, H. F and Yusof, F. (2012). Homogenity test on daily rainfall series in Peninsular Malasiya. Int J Contemp Math Sci, 7(1):9-22.

Kendall, M. G. (1975). Rank Correlation Methods, London: Charles Griffin.

Kotera, A, Nguyen, K. D., Sakamoto, T., Iizumi, T. and Yokozawa, M. (2014). A modeling approach for assessing rice cropping cycle affected by flooding, salinity intrusion, and monsoon rains in the Mekong Delta, Vietnam. Paddy Water Environ., 12 :343-354

Li, Z. L., Xu, Z. X. and Li, J. Y. (2008). Shift trend and step changes for runoff time series in the Shiyang River basin, northwest China. Hydrol. Process., 22 : 4639-4646.

Lobell, D. B., Schlenker, W. S. and Costa-Roberts, J. (2011). Climate Trends and Global Crop Production since 1980, Science, 333: 616-20.

Mann, H. B. (1945). 'Nonparametric tests against trend. Econometrica, 13:245-259.
Michiels, P., Gabriels, D. and Hartmann, R. (1992). Using the seasonal and temporal precipitation concentration index for characterizing monthly rainfall distribution in Spain. Catena, 19:43-58.

Nair, A., Joseph, K. A. and Nair, K. S. (2014). Spatio -temporal analysis of rainfall trends over a maritime state (Kerala) of India during the last 100 years. Atmos. Environ., 88:123-132.

Oliver, J. E. (1980). Monthly precipitation distribution: A comparative index. Professional Geograp., 32: 300309.

Pawar, P., Pal, S, Loria, N., Verma, M.R., Alam, N.M., Bhatt, V.K., Sharma, N.K. and Mishra, P.K. (2019). Variability and time series trends of rainfall and temperature in Indian Himalaya. J. Agrometeorol., 21(2): 220-223.

Pettitt, A. N. (1979). A non-parametric approach to the change point problem. J Appl Stat , 28(2) : 126-135.

Piao, S. L., Ciais, P. E. and Fang, J. Y. (2010). The impacts of climate change on water resources and agriculture in China. Nature, $467: 43-51$.

Rathore, L. S., Attri, S. D. and Jaswal, A. K. (2013). State level climate change trends in India. Meteorological Monograph, ESSO/IMD/EMRC/02/2013.

Sen, P.K. (1968). Estimates of the regression coefficient based on Kendall's tau. J. American Statis. Assoc., 63: 1379-1389.

Thomas, J. and Prasannakumar, V. (2016). Temporal analysis of rainfall (1871-2012) and drought characteristics over a tropical monsoon-dominated State (Kerala) of India, J. Hydrol, 534: 266-280.

Walsh, R. P. D. and Lawer, D. M. (1981). Rainfall seasonality: Description, spatial patterns and change through time. Weather, 36: 201-208.

Winingaard, J. B., Kleink Tank, A. M. G. and Konnen, G. P. (2003). Homogeneity of 20th Century European Daily Temperature and Precipitation Series. Int J Climatol, 23:679-692.

Zang, C. and Liu, J. (2013). Trend analysis for the flows of green and blue water in the Heihe River Basin, northwestern China, J. Hydrol., 502:27-36. 